\title{
Preparation Strategic and Results of Nursing Exam of Nursing Diploma in Indonesia
}

\author{
Yulia Wardani ${ }^{1} \&$ Agnes Mahayanti ${ }^{1}$ \\ ${ }^{1}$ Department of Nursing, School of Health Sciences of Panti Rapih, Yogyakarta, Indonesia \\ Correspondence: Yulia Wardani, MAN, Department of Nursing, School of Health Sciences of Panti Rapih, \\ Yogyakarta, Indonesia.
}

Received: October 1, 2018

Accepted: November 8, 2018

Online Published: November 13, 2018

doi:10.20849/ijsn.v3i3.504

URL: https://doi.org/10.20849/ijsn.v3i3.504

\begin{abstract}
Purpose: The readiness and strategies of management are important factors to gain higher passing grade on nursing national competency examination. This study analyzed the strategy and readiness of the managers to success try out and national competency examination and the readiness for administering Computer Based Test on national nursing competency examination in Indonesia.

Methods: This descriptive correlative research with population of 437 three years diploma in nursing institutions used quota and accidental sampling technique with 123 participants. The data were analyzed by using of frequency distribution, Spearman Rank Correlation and Multiple Regression analysis units.

Results: The results identified that $52,8 \%$ had accreditation status in level B. There were increasing results of the students that became better in the real results of national competency exam than the results on try-out exam. The preparation strategic 3 months before the exam was good $(57.7 \%)$ and $56.9 \%$ of the participants were not ready to deliver the national exam in Computer Based Test. There was a significant correlation between the results of the exam with accreditation status $(\mathrm{p}=.014)$, student body $(\mathrm{p}=.02)$ and 3 months preparation before the exam $(\mathrm{p}=.021)$. The most dominant predictor in success of the exam was the accreditation status with $\mathrm{p}$ value $=.005$.

Conclusions: Managers of three years diploma nursing degree have to prepare and have a good strategy for success in nursing national competency examination especially in managing student body, achieve good accreditation status and good strategic in preparing for attaining high passing grade on national competency examination.
\end{abstract}

Keywords: nursing competency exam, exam preparation strategic, diploma in nursing program

\section{Introduction}

The ASEAN's vision of 2020, which is to integrate the ASEAN economic activities as a single market is happening. Indonesia has to implement the MRA (Mutual Recognition Arrangement) and must respond to the social activities of the ASEAN Economic Community (AEC). The field of nursing and tourism are some free flow services that ready to compete in the era of these free market competition. Nurses who are have similar nursing education system and health systems will deliver the nursing competency exam and professional certification in the same and they will migrate from a wide variety of countries (Covell, Primeau, Kilpatrick \& St.Pierre, 2017).

Talking about potential power in global market competition, the human index achievements of Indonesian people is an important key that cannot be released from the concept of world's competition. When speaking about the concept of competition / competitiveness, then we cannot ignore of the term named competency.

Global Competitiveness Index in 2017-2018, showed that Indonesia in the position of 36th (from 137 countries) around the world (World's Economic Forum, 2018). This reflected that Indonesian people still have many potential aspects to be developed, including the potency of nursing activities. Talking about the competitiveness and nursing mobilization around the world, it founds that there is a lot of demand from the international market on exertion nursing. Unfortunately, Indonesia that produces a lot of three years diploma graduate nurses each year, has not able yet to meet the demand of that market. That figure do not includes the production of bachelor graduate nurses that was also a lot. In fact, Indonesia had been produced a surplus of nurses in some big provinces and cities, but also noticed the deficit of nurses in some remote areas. 
There has been a paradigm shifting in Indonesia education system for responding this situation, including in nursing education. The curriculum changes into competence- based curriculum in 2008 was believed to be the best way to produce good quality of graduate students who capable in responding the global challenges and counterbalancing free market competition. The Presidential Decree no 8 years 2012 about KKNI (Kerangka Kualifikasi Nasional Indonesia) or Indonesian National Qualifications Framework had been set parameters to counterbalance the education qualification (competence) in the regional and international levels. The curriculum on all sides should also be guided by the KKNI rules. Nursing education world responded this issue immediately. The issue of registration/STR, competency test and accreditation status are parameters to determine the quality of graduates and the quality of institutions.

The government, through the projects of Health Professional Education Quality (HPEQ) started working on a national competency test problem for exertion this health seriously since 2009 / 2010. In November 2014, the government finally held the competency test for the first time to the health profession that is administered by the Indonesian tribunal of health workers/Indonesian Health Commission. Even though the try out and the real exam it has been done for more than 27 times but the results of competence test on the first national examination until now had not yet meet the desired expectations. There were still about 50 percent of the participants in national competence examination who had not been managed and passed.

In fact, the competency test administration skills and the role of management for preparing competency test are also important factors that influence the achievement in exam. Shin et al (2017), stated that current written tests have several limitations in evaluating examinees' competency. The test itself might be a significant contributor factor that affects the success of the exam. Another perspective in contributing in lower grade results of this competency test because of some mistaken in registration process, miscommunication and the absence of specific strategies from the managers of three years diploma degree in nursing to create graduates with high capability so that the competency test will successfully attained. External factors of readiness and strategies of management were factors that need to be explored more seriously in attaining the best results of competency test (Koestler (2017), Lavin \& Rosario (2017), Kowitlawakul (2013) \& Simon (2013). What are the factors, best strategies and readiness of the three years nursing diploma program managers in preparing the graduate students in conjunction to produce successful try out national competency examination and successful national competency test? How the readiness of three years diploma degree in nursing institutions to deliver Computer Based Test of national nursing competency examination?

\section{Methods}

\subsection{Study Design}

This quantitative research used a descriptive correlative method. The first description was to inform the profile of the three years diploma degree in nursing, then followed by the strategies of the three years diploma degree in nursing in preparing try out and the real preparation for national competency examination. The profile was followed by the results of try out and real result of national competency examination in the last three years and the readiness of three years diploma degree in nursing to implement computer based test of national competency examination. Another approach was to look at the relationship between variables and to analyze the determinant variable that affects the result of national competency examination.

\subsection{Setting and Samples}

The research was done across Indonesia with the total population of 437 three year diploma program in nursing around Indonesia. Those three years diploma degree in nursing were the members of AIPViKI (Asosiasi Institusi Penyelenggara Pendidikan Vokasi Keperawatan Indonesia)/ the association of institution that administer the nursing vocation degree in Indonesia that divided for 14 regionals of AIPViKI. The quota sampling technique was used to gather participants in this study that in every region was taken $30 \%$ from total population. From that quota sampling technique, the researcher obtained for 130 participants. After the quota sampling was done, the accidental sampling technique was used to frame the eligible samples that returned the questionnaire from July to September 2017, and there were 123 participants.

\subsection{Instrument}

The instrument used in this research was developed by the researcher, consisting of 75 statements with the description as follows; 1). 25 items of the statement in which some words of the statement lead to a method of learning theory, learning practices, student center learning, performance of the lecturers, e-learning process and evaluation method. In order to ensure that the results would not fall to the false positive conclusion, the items of the instruments were mixed between positive and negative sentiment of the statements. It constructed by 13 
items that were positive learning done in management and 12 items were negative (means no / has not been carried out by the managers in three year diploma degree in nursing. 2). 25 items on the second segment were used to measure the preparation of management in preparing the students to face national competency examination which happened 3 months before the real examination be done. There were 18 positive statement items and some 7 items are negative (it no were carried out by the three year diploma degree in nursing). 3). The last segment consisted of 25 items that pictured out of the readiness of the three year diploma degree in nursing management to do the national competency examination on computer based test.

In each sentence of those items was filled by the individual/ participant with the category scales that was a dichotomy/ binary, which meant the participant got two answers; yes or no. To keep the reliability and validity of this instrument, the researcher conducted a pilot study to test the questionnaire to 15 participants (managers on three year diploma degree in nursing) and obtained the results of reliability test with the Cronbach's Alpha $=.89$.

\subsection{Data Collection/Procedure}

The data collection procedures were done by permission from the Head of AIPViKI (national and regional). After having that permission, the researcher contacted the secretary from each regional to give some lists of AIPViKI members in every regional including the name and address of the institution and also the contact number. Then the researcher did the communication and sent the instruments to the target participants by post/mail/email. The research did many calls and emails for reminding the participants to give back the instruments. Data collection was done in three months.

\subsection{Data Analysis}

The data analyzing were done by using statistic analysis units as follows: 1) descriptive analysis to describe data in a frequency distribution. This pictured out the profile of three years diploma degree in nursing, the provision strategy for success on national competency examination and the readiness in doing computer based of exam. 2) Spearman-rank correlation test to see the correlation across all variables. 3) Analysis of linear regression to analyze the determinant factors of the independent variables in supporting the success of national competency examination. In this analysis some steps will be done such as: a) the assumption of normality data; b) the Spearman Rank bivariate correlation test to see the tendency of the relations data. c) multiple regression analysis by using the test of coefficients determination used to measure what are the dominant variables that affect the dependent variable.

\section{Results}

In this study, 437 questionnaires were delivered to 14 regions/provinces of AIPViKI around Indonesia. The target samples with quota sampling technique were $30.0 \%$ from the total population which was 130 . The response number of the participants was 123 in July to September (3 months response time). 65 of 123 (52.8\%) participants hold the accreditation status at very good level (B) from the IAAHE (Indonesian Accreditation Agency for Higher Education in Health). A number of institutions that gained the accreditation from IAAHE were $78(63.4 \%)$ and the rest were from another accreditation committee.

Another distribution of demographic characteristic of the participants were; three years diploma institutions who had student body of 101 to 200 student was $34.2 \%$. Amount of three years nursing program has the length of age in running the college for 11-20 years old as $46(37.4 \%)$ institutions. There was 70 of $123(56.9 \%)$ three years nursing diploma institutions not ready to administer the CBT (Computer Based Test) for the national examination process. 72 institutions of $123(58.5 \%)$ conducted the learning process (method, material, facilities, etc) which did not supported the success of the final national competency examination and 71 of 123 (57. 7\%) had prepared the exam three months before the exam in good manner.

\subsection{The Distribution of Results on the Try-out of the National Competency Exam and Real National Competency Exam}

The distribution of results on the try out national competency examination and the real result of the national competency exam in the last three years were described the tendency of increasement of participation of the three years diploma in nursing program in try-out of examination and the increasement of good result (passing grade 50\% to 75\%) [Table 1]. Then the result of the real examination for the last three years indicates also that the increasement of participation on real exam, stabilization of the result with passing grade $50 \%$ to $75 \%$. The good description were the significant increasement of the result with $76 \%$ to $99 \%$ and $100 \%$ passing grade compare between try out result and real result of national examination [Table 1 and 2]. 


\subsection{The Result of Correlation Analysis Among the Variables}

The correlation analysis shows that there is significant correlation between accreditation status with the student body with $p$ value $=.003$ and between the result of the try-out with real result of the national examination with $p$ value $=.000$.

The correlation between the passing grade of national competency test with accreditation status was exist with $p$ value $=.014$ and the number of student body with $p$ value $=.002$ and with strategy of the manager 3 months before the real exam $(p=.021)$. [Table 3]

\subsection{Determinant Factor Analysis Result}

The determinant analysis informs that the accreditation status is the major determinant factor that contributes the level of the passing grade of the national competency examination with $p$ value $=.005$. [Table 4]

Table 1 . The results of try-out of national competency examination for last three years

\begin{tabular}{llcccccc}
\hline No. & Chategory & \multicolumn{2}{c}{$\mathbf{2 0 1 4}$} & \multicolumn{2}{c}{$\mathbf{2 0 1 5}$} & \multicolumn{2}{c}{$\mathbf{2 0 1 6}$} \\
& & $\mathbf{N}$ & $\boldsymbol{\%}$ & $\mathbf{N}$ & $\mathbf{\%}$ & $\mathbf{N}$ & $\mathbf{\%}$ \\
\hline 1 & No participantion & 30 & 24 & 24 & 11 & 18 & 15 \\
2 & Bad, with prosentase less than 50\% & 24 & 19 & 35 & 28 & 35 & 28 \\
3 & Good, with prosentase from 50 \% to 75\% & 38 & 31 & 35 & 28 & 41 & 33 \\
4 & Very good, with prosentase from 76 \% to & 26 & 21 & 37 & 30 & 27 & 22 \\
5 & 99\% & 5 & 4 & 2 & 2.15 & 2 & 3 \\
& Excellent, 100\% pass the exam & 123 & 100 & 123 & 100 & 123 & 100 \\
\hline
\end{tabular}

Table 2. The results of try-out of national competency examination for last three years

\begin{tabular}{llcccccc}
\hline No. & Chategory & \multicolumn{2}{c}{$\mathbf{2 0 1 4}$} & \multicolumn{2}{c}{$\mathbf{2 0 1 5}$} & \multicolumn{2}{c}{$\mathbf{2 0 1 6}$} \\
& & $\mathbf{N}$ & $\mathbf{\%}$ & $\mathbf{N}$ & $\mathbf{\%}$ & $\mathbf{N}$ & $\mathbf{\%}$ \\
\hline 1 & No participantion & 4 & 3 & 1 & 8 & 0 & 0 \\
2 & Bad, with prosentase less than 50\% & 32 & 26 & 20 & 16 & 34 & 28 \\
3 & Good, with prosentase from 50\% to 75\% & 38 & 31 & 31 & 25 & 29 & 24 \\
4 & Very good, with prosentase from 76 \% to & 43 & 35 & 66 & 54 & 57 & 46 \\
& $99 \%$ & 6 & 5 & 5 & 4 & 3 & 2 \\
5 & Excellent, 100\% pass the exam & 123 & 100 & 123 & 100 & 123 & 100 \\
\hline
\end{tabular}

Table 3. The correlation between result of success national competency nursing examination with accreditation status, students' body and the preparation strategic of institutions

\begin{tabular}{clcc}
\hline No. & & \multicolumn{2}{c}{ Examination Result } \\
& Variables & Correlation coefficient & Sig .(2-tailed) \\
\hline 1. & Accreditation Status & $-.259^{* *}$ & .014 \\
2. & $\begin{array}{l}\text { Student body } \\
\text { 3. }\end{array}$ & $.383^{* *}$ & .002 \\
& $\begin{array}{l}\text { Preparation Strategic } \\
\text { For 6 semester }\end{array}$ & .049 & .643 \\
& $\begin{array}{l}\text { Preparation strategic 3 months } \\
\text { before the exam }\end{array}$ & $.799^{* * *}$ & .021 \\
\hline
\end{tabular}


Tabel 4. Result of coefficients analysis

\begin{tabular}{|c|c|c|c|c|c|c|}
\hline Model & & $\begin{array}{l}\text { Unstandardized } \\
\text { Coefficients }\end{array}$ & Std. Error & $\begin{array}{l}\text { Standardized } \\
\text { Coefficients } \\
\text { Beta }\end{array}$ & $\mathrm{t}$ & Sig. \\
\hline 1.000 & (Constant) & 2.332 & .797 & & 2.925 & .004 \\
\hline & Age of the program & .053 & .118 & .040 & .454 & .651 \\
\hline & Accreditation status & -.494 & .172 & -.270 & -2.864 & .005 \\
\hline & Student body & -.059 & .088 & -.062 & -.677 & .500 \\
\hline & $\begin{array}{l}\text { Learning strategic for } 6 \\
\text { semester }\end{array}$ & .067 & .180 & .034 & .373 & .710 \\
\hline & $\begin{array}{lll}\text { Preparation } 3 & \text { months }\end{array}$ & & 181 & 152 & 1713 & 080 \\
\hline & The readiness for CBT & .104 & .181 & .051 & .575 & .567 \\
\hline
\end{tabular}

a. Dependent variable: passing grade of real exam

\section{Discussion}

The accreditation status, the size of student body, the age /length of time of the manager administered the program, the learning strategic and the preparation for the final exam are really important to gain the success of achieving high passing grade of the final exam. The data on this research was emphasizing those matters that contributed a lot for establishing the good quality and productivity of those institutions. The experience of the manager in managing intrinsic and extrinsic factors which affecting the academic performance will also important for the final passing grade achievement. Those intrinsic predictors in successful of study of a student were in its first semester are self-esteem and self-efficacy. Other intrinsic factors were the grade of entrance test and admission criteria (Ortega, 2013). The admission test become a significant factor to become one of predictor to contrive the assessment, designing learning and help the students in a learning process in their first year (Kowitlawakul, 2013). Age, background the culture, education background, academic accomplishments, thinking style, learning style, personality style and coping strategic style were also regarded as an intrinsic factors (Abdilah, 2016). Okanga, Ogur \& Arudo (2017) also emphasized that admission criteria is an important factor that influence the exam performance of the students. The raw input of the students will be determinant element on the process and the output of learning.

This research identified that $55(61.1 \%)$ of the institution that administer three years diploma in nursing were not ready for doing CBT examination test. It understood that because of the members of AIPViKI spread out around the archipelago islands and not all the provinces are supported by good technology. Another reason was the national competency examination itself just started at the end of year 2013. Meaning many innovations and models of exam are still in developing process. CBT is on the test methods competency test performed with used of computer facility and held all the process through online. The determination of the place for CBT competency test / used compliant and as determined by LPUK-Nakes. Institutions must have workstations according to the terms of the computer in case of personal computer that was invented belonging to educational institutions (unit consisting of central proceeding) CPU, the screen, keyboard and mouse and connection to the internet that fulfills the requirements of at least in supporting the implementation of the competence with the CBT standard (Ristekdikti, 2016). Good facilities resources including the technology in learning are important for the success of final examination (Stander \& Herman, 2017).

Some institutions found in this research where 72 from $123(58.5 \%)$ delivered the learning process (method, material, facilities) that were not support the success of final national competency examination and 71 from 123 (57.7\%) were doing their preparation three months before the exam in good manner. Managing the students in attending a final exam influenced by the length of time a student undergo the education and number of cases met during the practice experiences (field practice facilities, the location, time and experience students through specific) rotation in the clinical areas. The period of time in managing nursing institution was important experience to achieve best performance in academic achievement. That students have the achievement more than 3, 27 (4 scale) had a great potential to succeed attending a final examination. Those factors since the first learning strategy, capacity / verbal skill, and mastery basic learning of the subjects, the ability to think critically, self efficacy, experience the use of strategies and methods of case studies and abilities in clinical practice were some factors that influences the success of final exam (Simon, Mcginniss, Krauss (2013). Experiences of simulation learning, problem solving, debriefing, reflective learning, peer review scenario and writing and 
critical thinking were also important for that matter (Koestler, 2017).

Management of curriculum, academic achievement development, learning style, capacity developments, staff roles and responsibilities, research development, academic leadership were also important skills to be hold by the managers (Stander \& Herman (2017), Abdilah (2016), Herrera \& Blair (2015) \& Luhanga (2014)). The institutional characteristics will also influence the performance of nursing students. Another crucial keys are faculty years of experience, class attendant policy also important factors that affected the result of final exam (Okanga, Ogur \& Arud0, 2017). The learning achievements of the students also affected by the competency of lecturers/educators. A lecturer will projecting some values, inspiring the students the values of enthusiasm, clarity of thinking, sharp of planning and organizing the matter, and way of judging and evaluating the situation. The determining factor that important in the success of the students in competency test is the role of lecturers / educator (Smimou \& Dahl, 2017).

When the manager in those three years diploma program were increasing their educational management skills then the good accreditation will be the positive consequence they have. Accreditation achievement has close relationship with the success of the management to achieve a good performance of final examination (Cetin \& Cetin (2017), Stander \& Herman (2017), Herrera \& Blair (2015) \& Blanco (2015)). This research noticed that the higher of status accreditation is the higher of the passing grade in final examination.

The distribution of result on try-out national competency examination and the real result of national competency exam for last three years were described the tendency of increasement of participation of the three years diploma in nursing program in try-out of examination and the increasement of good result (passing grade $50 \%$ to $75 \%$ ). [Table 1]. Then the result of real examination for last three years indicated also that the increasement of participation on real exam, stabilization of the result with passing grade $50 \%$ to $75 \%$. The good description were the significant increasement of the result with $76 \%$ to $99 \%$ and excellent passing grade compare between try out result and real result of national examination. This research indicated that some institutions failed to do some necessary learning activities for achieving high passing grade (Azizi, Hajibagheri \& Adib, 2015). Lesson activities in the classroom with learning method in a case study simulation were really important (Eyikara \& Baykara (2017) \& Sprinks (2013)). Reviewing the questions after periodic of exam, conditioning the question in vignette manner and habituating the students to make bullets and not cross-check model in answering the question were also significant results in this study. Students who applied necessary strategies because of their try out experiences will act more carefully during the real exam (Standaer \& Herman, 2017). The internal structures of the item development are multi-dimension and have a different association among dimensions (Seo, Choi \& Huh, 2017). It was expected that every students has learning experiences and competencies in all variety of nursing clinical area such as $\mathrm{OB}$, pediatric, medical surgical, mental health, emergency and critical area. Students who are practicing the review, responses and questions analyzing frequently seem have more chance to gain higher passing grade in final exam. The students are more sensitive to judge the meaning of the exam (Cetin (2017) \& Azizi, Hajibagheri (2015).

Students were trained to develop verbal skill and critical thinking of a case was the important learning experience that the students should have. These activities and continues in the clinic where the skill real students applied in the real environment. Early diagnostic of extrinsic components to predict the students were potency were curriculum, pedagogy strategies, pre-clinical standards, and academic guidance by experts (Baptiste \& Shaefer (2015) and Amankwaa, Agyemang and Boateng (2015). Other factors affecting the success of the test were the try out activities, the duration of the test, the purpose of learning of the subject, preparation questions for learning, debriefing (question and answer) and discernment to important elements (Abdilah (2016), Lavin, Rosario (2013) \& Simon \& Krauss (2013). Aside from those factors, there are also factors that affecting students in the process of achieving good final competency exam. Those factors are; the quality of the lectures and clinical instructors, management of planning until evaluating the learning program, learning methods used, infrastructure learning available, the use of up dated information technology and the availability of other learning resources (Eyikara \& Baykara (2017) \& Abdilah (2016)). Combining innovative and high fidelity simulations that delivered in learning process and the clinical experience opportunities will increase the results of the exam. (Curl, Smith, Chisholm, Mc gee \& Das, 2016).

Begin in last 2013, the first try out and real exam until the ninth in last 2017, national competency examination for nursing students were a hot issue to be attended in Indonesia. Some students had no desire to attend the try out, yet the result on this study noted that there is a significant correlation between try out and real result of final examination. The roles of institution in achieving the success of the national competence examination and accreditation can be done in many ways such as supporting the students in try out activity, registration process, giving clear information about the examination process, preparing good learning strategic for success in the 
examination, good learning facilities, buildings, library and so on. The package of Indonesian nursing competency test composed of 180 items and must be settled in 180 minutes. It is not about "recollection" assessments but a reasoning-analytical question in accordance with the level of a diploma. The majority of the problems are located in the level of $\mathrm{C} 3$ and $\mathrm{C} 4$ of Bloom's taxonomy. Composition of the test are related to professional practices, ethical and legal issues and culture sensitive that about $15 \%$ to $25 \%$, related nursing care management around $65 \%$ to $75 \%$ and professional development is about 5\% to $15 \%$. The test also composes of cognitive domain about $40 \%$ to $50 \%$, procedural domain is $45 \%$ to $55 \%$ and the domain of affective is $5 \%$ to 10\% (Smimou \& Dahl (2017) \& Ristekdikti (2016)). In accordance with the Minister for Health decree no.161 year 2009 about the obligation to administer a competency test for every nurse, and it cannot be excluded. To ensure this issue, the government has issued a regulation health minister no.1796 year 2011 about health workers registration process and this guide was published for nursing higher institutions in Indonesia. This issue was explained that all health workers including nurses must undergo competency examination as a requirement to obtain registration certificate as a nurse (Abdilah, 2016).

Responding of this composition of test, every manager in nursing college is doing their effort for preparing their students to face up this final examination. One of that preparation was urging their students to do the try out competency test regionally or nationwide, which is held twice in about June / July and September (Abdilah, 2016). Regional/ provincial try out has been done at least one month before national try out. National try out has been started more or less about 17 times since 2013, while the real competency test for three years nursing diploma has done about 12 times.

The correlation analysis said that there were significant relation between the accreditation status with student body ( $p=.003)$, between the result of try-out with real result of the national examination $(p=.000)$. The correlation between the passing grade of national competency test with accreditation status $(p=.014)$, the number of student body $(p=.002)$ and with strategy of the manager 3 month before the real exam $(p=0.021)$. [Table3]. The success of students in attending a final exam influenced by length of time students follow education and many cases that had ever met for field practice (of facilities cases, location, time and experience students through rotation on an area of specific). In addition, that college students are that has index achievement more than 3.27 (the scale of 4) has a great potential to succeed attending a final exam (Lawler (2017) \& Ortega, Burns, Hussey, Schmidt \& Austin (2013)). That strategy plan learn since the first year, capacity or ability of verbal, long learn to the subject basic, the ability reflect critical, self-efficacy, experience the use of strategy and methods case study and ability practices clinic (Simon, Mcginniss \& Krauss ,2013). One of learning activities can be learning activities in the class by using the method of simulation and case study. In that methods students trained to develop the ability of verbal and critical thinking of a case. Simulation method will lead the students to have good critical thinking, sharp clinical decision making skill and fewer mistakes in their clinical setting experiences (Smimou, Dahk (2017) and Eyikara \& Baykara (2017)).

The accreditation status was found as dominant factor in achieving high passing grade on the national competency examination successfully. Determinant analysis informed that accreditation status was the major determinant factor that contributed the level of passing grade of national competency examination with $p$ value $=.005$ [Table 4]. Through accreditation process the quality of strategic planning, students activities, human resources, curricula, facilities and research activities are scored and evaluated. In increasing the quality of that accreditation the managers need a lot of time and skill in managing and administrating the education degree program in nursing higher institutions. The students should be involved actively in achieving expected competences in a learning process. Competence model in a nursing education field also was developed based on the need of the users (Lawler (2017) and Baptiste \& Shaefer (2015)). Competence has been set as competence standard of 3 years nursing graduates and was measured by a mechanism and called the national competency test.

\section{Conclusion}

Based on the past three years national examination experiences data of diploma in nursing program noticed that sixty five of 123 participants (52.8\%) hold the accreditation status in very good level (B) from the IAAHE (Indonesian Accreditation Agency for Higher Education in Health). 78 institution (63.4\%) gained the accreditation from IAAHE and the rest were from another accreditation committee. Three years diploma institution who had student body of 101 to 200 students was $34.2 \%$, Amount of three years degree program has the length of age in running the college for $11-20$ years old as 46 institutions (37.4\%). There was 70 from 123 three years nursing diploma institutions (56.9\%) not ready to administer CBT (Computer Based Test) for national examination process. 72 institutions from 123 (58.5\%) was delivered the learning process (method, material, facilities) which was not support the success of final national competency examination and 71 from 123 
$(57.7 \%)$ were doing their preparation three months before the exam in good manner.

The researcher explored that accreditation status, the size of student body, the learning processes that had been done along the three years diploma program and special preparation program 3 months and try out process before the national competency examinations, try out process before the real exam were significantly correlated with the achievement and success of national competency examination. The accreditation status was the major determinant factor that contributed the level of passing grade of national competency examination.

\section{Implication for the Practice}

The results of this research provided recommendation that manager in three years diploma in nursing program should urge the students to have an experience in try out examination, to administer the learning process with a lot of case study, simulations methods along of 3 years process of learning. Special preparation for final exam should be done through various activities such as; reviewing the exam questions, analyzing the exam, delivering try out, developing CBT modes for test/exam in order to increase the sensitivity of the students in judging the questions and increasing the level of anxiety in facing the exam. The manager in higher education in nursing institutions should administering the learning processes, curriculum, developing finance and facilities resources, developing capacity of the managers in running the higher educational program, increasing research activities in order to gain higher score in accreditation and higher score of nursing competency examination.

\section{References}

Abdilah, A. (2016). Analisis Faktor-Faktor Yang Mempengaruhi Kelulusan Uji Kompetensi Ners Indonesia. Jurnal Penelitian Administrasi Publik, 2(2), 373-380.

Amankwaa, I., Agyemang-Dankwah, A., \& Boateng, D (2015). Previous Education, Sociodemographic Characteristics and Nursing Cumulative Grade Point Average as Predictors of Success in Nursing Licensure Examinations. Nursing Research and Practice. https://doi.org/10.1155/2015/682479

Azizi-Fini, I., Hajibagheri, A., \& Adib-Hajbaghery, M. (2015). Critical Thinking Skills in Nursing Students: a Comparison Between Freshmen and Senior Students. Nursing and Midwifery Studies, 4(1), 25721. https://doi.org/10.17795/nmsjournal25721

Baptiste, D., \& Shaefer, S.M. (2015). Online module to assure success as prelicensure nursing students transition to professional practice. Quarterly Review of Distance Education, 16(4), 1-6.

Blanco Ramírez, G. (2015). Translating quality in higher education: US approaches to accreditation of institutions from around the world. Assessment \& Evaluation in Higher Education, 40(7), 943-957. https://doi.org/10.1080/02602938.2014.960361

Cetin, F., \& Cetin, S. (2017, January). The Management Skills of Exam Process for Undergraduate Students. Journal of Education and Practice, 8(12), 9-14. ERIC, Ipswich, MA.

Covell, C.L., Primeau, M.D., Kilpatrick, K., \& St-Pierre, I. (2017). Internationally educated nurses in Canada: predictors of workforce integration. Human Resources for Health, 15(1), 26. https://doi.org/10.1186/s12960-017-0201-8

Curl, E.D., Smith, S., Chisholm, L.A., McGee, L.A., \& Das, K. (2016). Effectiveness of Integrated Simulation and Clinical Experiences Compared to Traditional Clinical Experiences for Nursing Students. Nursing Education Perspectives (National League for Nursing), 37(2), 72. https://doi.org/10.5480/15-1647

Eyikara, E., \& Baykara, Z.G. (2017). The Importance of Simulation in Nursing Education. World Journal On Educational Technology: Current Issues, 9(1), 2-7. https://doi.org/10.18844/wjet.v9i1.543

Getha-Taylor, H., Hummert, R., Nalbandian, J., \& Silvia, C. (2013). Competency Model Design and Assessment: Findings and Future Directions. Journal of Public Affairs Education, 19(1), 141-171. https://doi.org/10.1080/15236803.2013.12001724

Herrera, C., \& Blair, J. (2015). Predicting Success in Nursing Programs. Research in Higher Education Journal, 28.

Koestler, D.L. (2015). Improving NCLEX-RN First-Time Pass Rates with a Balanced Curriculum. Nursing Education Perspectives (National League for Nursing), 36(1), 55-57. https://doi.org/10.5480/11-591.1

Kowitlawakul, Y., Brenkus, R., \& Dugan, N. (2013). Predictors for Success for First Semester, Second-Degree Bachelor of Science in Nursing Students. International Journal of Nursing Practice.

Lavin, J., \& Rosario-sim, M.G. (2013) .Understanding the nclex: How to Increase Success on the Revised 2013 
Examination. Nursing Education Perspectives, 34(3), 196-198.

Lawler, P. (2017). Higher Education vs. Competency and Diversity: An Afterword. Modern Age, 59(3), 73-79. Professional Development Collection, Ipswich, MA.

Luhanga, F.L., Larocque, S., MacEwan, L., Gwekwerere, Y.N., \& Danyluk, P. (2014). Exploring the Issue of Failure to Fail in Professional Education Programs: A Multidisciplinary Study. Journal of University Teaching \& Learning Practice, 11(2), 1-24.

Okanga, A., Ogur, J., \& Arudo, J. (2017, January). Institutional Characteristics Influencing Bachelor of Science Nursing Student Performance in the Nursing Council of Kenya Licensure Examinations in Kenya. Journal of Education and E-Learning Research, 4(1), 28-36. ERIC, Ipswich, MA.

Ortega, K.H., Burns, S.M., Hussey, L.C., Schmidt, J., \& Austin, P.N. (2013). Predicting Success in Nurse Anesthesia Programs: An Evidence-Based Review of Admission Criteria. AANA Journal, 81(3), 183-189.

Pritasari, K. (2014). Peran Institusi Pendidikan Dalam Meningkatkan Kualitas Lulusan Yang Kompeten Melalui Uji Kompetensi, Pusat Standarisasi, Sertifikasi dan Pendidikan Berkelanjutan SDM Kesehatan. Jakarta.

Ristekdikti. (2016). Panduan Pelaksanaan Uji Kompetensi Program Diploma III Kebidanan, Diploma III Keperawatan dan Profesi Ners April Tahun 2016.

Seo, D.G., Choi, Y., \& Huh, S. (2017). Usefulness of the DETECT program for assessing the internal structure of dimensionality in simulated data and results of the Korean nursing licensing examination. Journal of Educational Evaluation for Health Professions, 14, 32. https://doi.org/10.3352/jeehp.2017.14.32

Shin, S.J., Kim, Y.K., Suh, S.R., Jung, D.Y., Kim, Y., \& Yim, M.K. (2017). Perception survey on the introduction of clinical performance examination as part of the national nursing licensing examination in Korea. Journal of Educational Evaluation for Health Professions, 14, 26. https://doi.org/10.3352/jeehp.2017.14.26

Simon, E.B., Mcginniss, S.P., \& Krauss, B.J. (2013). Predictor variables for nclex-rn Readiness Exam Performance. Nursing.

Smimou, K., \& Dahl, D. (2012, January). On the Relationship Between Students' Perceptions of Teaching Quality, Methods of Assessment, and Satisfaction. Journal of Education for Business, 87(1), 22. MasterFILE Premier, Ipswich, MA.

Sprinks, J. (2013). Proposed competency tests for overseas nurses win RCN's support. Nursing Standard, 28(10), 7. https://doi.org/10.7748/ns2013.11.28.10.7.s2

Stander, E., \& Herman, C. (2017, September). Barriers and challenges private higher education institutions face in the management of quality assurance in South Africa. South African Journal of Higher Education, 31(5), 206-224. Education Research Complete, Ipswich, MA. https://doi.org/10.20853/31-5-1481

World's Economic Forum. (2018). Global Competitiveness Index. Retrieved Sept 27, 2018, from Report.weforum.org/global-competitiveness-Index/2017-1018/competitiveness-ranking/retrieve

\section{Copyrights}

Copyright for this article is retained by the author(s), with first publication rights granted to the journal.

This is an open-access article distributed under the terms and conditions of the Creative Commons Attribution license (http://creativecommons.org/licenses/by/4.0/). 